2017 , volume 6, issue 4

Buszko, A. (2017). The level of shadow economy in Warmińsko-Mazurski and Kujawsko-Pomorski regions. Copernican Journal of Finance \& Accounting, 6(4), 9-21. http://dx.doi.org/10.12775/ CJFA.2017.020

\author{
AndRzeJ BuszKo* \\ University of Warmia and Mazury in Olsztyn
}

\title{
THE LEVEL OF SHADOW ECONOMY IN WARMIŃSKO-MAZURSKI AND KUJAWSKO-POMORSKI REGIONS
}

Keywords: shadow economy, level, region, roots, effects, differentiation.

J E L Classification: D78, H11, H2, K42.

\begin{abstract}
This paper offers the appraisal of the shadow economy in two regions in Poland: Kujawsko-Pomorskie and Warmińsko-Mazurskie. The MIMIC approach was applied. In the begging of analyzed period the higher level of shadow economy was perceived in Kujawsko-Pomorski region. Than the situation was changed. The slowly increased of shadow economy was observed in Warmińsko-Mazurski region but in Kujawsko-Pomorski region gradually the level of shadow economy declined.
\end{abstract}

\section{INTRODUCTION}

Shadow economy is an important but underestimated economics category. The shadow economy exists in any country and just varies from its level and category. According to Schneider, the 'shadow economy', defined as currently unregistered economic activities that contribute to the officially calculated (or observed) Gross National Product (GNP), amounted to $16 \%$ of the official output

Date of submission: April 12, 2018; date of acceptance: May 12, 2018.

* Contact information: buszko@uwm.edu.pl, Finance and Banking Department, Faculty of Economy, University of Warmia and Mazury in Olsztyn, Michała Oczapowskiego 2, 10-900 Olsztyn, Poland, phone: +48 8952339 63; ORCID ID: https://orcid.org/00000003-0600-4646. 
in Organization for Economic Cooperation and Development (OECD) countries, $39 \%$ in developing countries and up to $40 \%$ in transition countries (Schneider, 2005, p. 2). In spite of that definition based on literature review one can find other descriptions like: parallel, illegal, unreported, grey zone, underground, unrecorded, and so on. There are around 20 different definitions on the shadow economy (Buszko, 2016, p. 2). Each single designation reflects to different economic category. That why the results of the shadow measurement are quite often varies. This is because researches, academics refer to different classifications. There is an important distinguish between shadow economy and black economy (Aldridge \& Decary-Hetu, 2015, p. 11). The black economy covers the illegal activity which is against criminal code and can arise very often no economic effects :like murdering. But shadow economy is always connected with economic effects and violates mostly civil code - related to business operation mostly. Even though there is a constant challenge with lowering the size of shadow economy, unfortunately the result of it its relatively small one. Probably the reason is that shadow economy and official one are bouncy connected, and each other can not persist without other part. Interesting remark is provided by Chen - there are at least three schools of thought on link between shadow and formal economies: dualism, structuralism, and legalism. The "dualists" argue that shadow activities have few linkages to the official economy but, rather, operate as a separate sector. This approach is based on the neoclassical hypothesis that rigidities in the official sector, introduced through legislation or negotiation, segment the market. The dualist hypothesis asserts that these two sectors are subsidiaries through common factors that lead to the flow of workers and activities from formal to the shadow economy. The "structuralists" consider the shadow and formal sectors as intrinsically linked. Formal enterprises promote informal production and employment relationships with subordinated economic units and workers to reduce their input costs (Chen, 2007, p. 4; Salatin \& Jahani, 2016, p. 7). The roost of the shadow economy are generally recognized:

1) The high level of taxation and all other social burdens,

2) The complicated and contradicted law system, especially tighten with business environment,

3) The high level of corruption,

4) The high level of organized crime,

5) The low quality of institutional organizations (Laruelle, 2008, p. 8). 
Buszko draws attention to cultural implications. The category of culture, particularly some dimensions of it like power distance, uncertainty avoidance, and individualism vs. collectivism have strong impact on the shadow economy level (Buszko, 2018, p. 1). The effects of the shadow economy are incomprehensible. Some researches states that shadow economy affects legal economy in depraved way, but some notice positive results. Schneider based upon his research states that $66 \%$ of earnings in the shadow economy is quickly spent in formal sector. Secondly the government is not so obliged to assure higher social support for unemployment and underprivileged people (Schneider, 2010, p. 15). Companies operating in the shadow economy influence on the legal ones, so legal firms should put more effort on competitiveness and innovation. Additionally to that the cost of entry to the shadow economy are quite low ones, so entrepreneurs without sufficient capital can start business activity (Buszko, 2017a, p. 3). After some time they may move to legal performance. But more researches are agree that shadow economy causes the problems for all economy. According to the Fraser Institute studies, a growing shadow economy is the sign that the democracy works bad, citizens condemning governments policies through an economic behavior, protesting to the law and regulations, and additionally influenced the usual consumption spending, and mainly those for long term purpose (Florea \& Schiop, 2008, p. 12). More dangerous results of shadow economy are pointed out by Mara. The shadow economy has a strong social impact and because of that it is closely linked to a number of phenomena such as corruption, crimes of various types, drugs, mafia type organizations, labor exploitation through a stock black money laundering, human rights violations environmental pollution, etc. Politically, the shadow economy is seen as having negative effects because it emits false signals and induces decision makers as inadequate macroeconomic strategy. As a consequence, any macroeconomic policy on the tax system, unemployment, inflation, savings, social security, productivity and competitiveness is weak (Mara, 2012, p. 21). Methods applied to shadow economy measurements can be divided into two main categories. Direct and indirect ones. Direct methods include first of all surveys, straight interviews, questionnaires. Such an approach has generally more weak points. In this way just the opinion on the shadow economy is achieved, not accurate data. But from the other hand this methodology is widely used in social science, including economics. General problem is devoted to the credibility of obtained answers. Answers providers are sometimes not interested to contribute true information. They could be scared since they might be charged with the 
action in the shadow economy frames. Discrepancy between national expenditure and income statistics is the basement for indirect methods. Those methods are connected with money supply approach, resource estimation and labor force evaluation (Buszko, 2017b, p. 4).

\section{LITERATURE REVIEW}

There are quite lot of studies devoted to the level of shadow economy on country level. Such researchers were and still have been carrying out in many countries. Academics, politics, legislators supposed to know not only the level of the shadow economy, but what is more important the effects, implications for stabilization policy, effectiveness of allocation, tax evasion, entrepreneurship, innovation, as well (Adam \& Ginsburgh, 1985, p. 11; Christopoulos, 2003, p. 7; Dell'Anno, 2003, p. 6). Some investigators tried to identify the patterns of shadow economy among countries in regional surround. Dell'Anno and his team made a such research on the shadow economy among France, Spain and Greece. The unemployment rate, the fiscal burden and self-employment are the main causes of the shadow economy in those countries and confirm that an inverse relationship exists between the official GDP growth rate and an unofficial economy (Dell'Anno, Gómez-Antonio \& Pardo, 2007, p. 15). However, there is much less research on regional shadow economy estimations. Interesting investigation was carried out by Bilonizhko in 26 Ukrainian and 79 Russian regions affected by the shadow economy. She not only assessed the level of shadow economy in the regions but pointed out the main roots of it. She found that tax pressure had a significant positive effect on the shadow economy. Agricultural and industrial specializations both had significant positive impacts on the hidden sector almost equal in size. Unemployment had a significant negative effect on the shadow economy, which may be explained by the fact that today's shadow economy was mostly maid up of the officially employed economic agents, who used different schemes to avoid taxation. Based on Bilonizhko finding no substantial deviation of the shadow economy size across regions, and she came to the conclusion that policy targeted at reducing the hidden economy size may suffice at the country's level without going deeply into region's specifics (Bilonizhko, 2006, p. 32). Komarova considers the regional differences of shadow economy on the number of large companies. This is because large enterprise can have better unofficial relationships with authorities than small ones, therefore large enterprises may be more involved into the shadow econ- 
omy activity (Komarova, 2003, p. 25). In contradiction to Komarova Nikolayenko, Lissovolic and MacFarquar came to another conclusion. They state that the number of small and medium firms is crucial for shadow economy development. Such companies are more eager to operate illegally and such activity is difficult to be traced out, so regions with the higher number of SME will face higher level of shadow economy (Nikolayenko, Lissovolic \& MacFarquar, 1997, p. 18). Wiseman examined regional shadow economic activity in 50 US states. Results suggest that tax and social welfare burdens, labor market regulations, and intensity of regulation enforcement are important determinants of the underground economy. Among the states, Delaware, on average, maintains the smallest shadow economy at $7.28 \%$ of GDP; Oregon, on average, has the second smallest shadow economy at 7.41\% of GDP; followed by Colorado, averaging $7.52 \%$ of GDP, rounding out the three smallest shadow economies in the US. West Virginia and Mississippi, on average, have the largest shadow economies in the US as a percent of GDP (9.32 and 9.54\%, respectively (Wiseman, 2013, p. 19). Vorobyev estimated the size of unofficial (informal) sector in 67 regions of Russian Federation using electricity consumption method. He proved that 10 regions with informal economy share above 60\%: Ingushetia, Moscow, Dagestan, Kalmykia, Altay Republic, Krasnodar region, Kabardino Balkaria, Kaliningrad, Astrakhan, and Saint-Petersburg. Southern small regions are likely to have high informal economy share because they have a large share of small business and low government control over economic activity (Vorobyev, 2015, p. 14). Tafenau, Herwartz and Schneider made an interesting research on the level of shadow economy in the regions of European Union. For this purpose the multiple-indicators multiple-causes approach combined with elements of spatial econometrics was implemented. The analysis show that the shadow economy is most extensive in Eastern and Southern Europe, confirming results from previous literature. Within countries, the poorest regions tend to exhibit the highest shadow economy quotas. The smallest extent of shadow activities is obtained for the Netherlands and the United Kingdom, while in Poland the shadow economy is most extensive (Tafenau, Herwartz \& Schneider, 2010, p. 7). This research is partly consistent with the study of Putniņš and Sauka. They measured the level of the shadow economy using the direct approach - interviewing managers of companies from Lithuania, Latvia and Estonia. The highest level of shadow economy was noticed in Latvia (ca. 30\% GDP) , the smallest one in Lithuania nearly 17.2\% GDP (Putniņš \& Sauka, 2015, p. 19). Krakowski analyses the determinants of the size of the informal economy using cross 
country regressions. Two sets of global data using indirect estimation techniques and the perception of business leaders for 109 countries as well as a regional set for Latin America based on direct data were applied to estimate the size of the informal economies. Indirect estimation techniques arrive at higher estimates of the size of the informal economy than the perceptions of business leaders because they include not only the (fundamentally legal) activities of the informal sector. The size of shadow economy was dependent on the level of development. Well developed countries faced lower level of shadow economy than poorer ones (Krakowski, 2005, p. 32). Thießen examined 38 OECD countries and came exactly to the same conclusions (Thießen, 2010, pp. 7-9). Similar remarks were provided by Elgin and Öztunali. They estimated the size of the shadow economy in a 161-country panel data framework. Even though they developed two-sector dynamic general equilibrium model, the high level of shadow economy was noticed in less developed regions in the world (Elgin \& Öztunali, 2015, p. 9). Opposite statement provided Cassel and Cichy. Based on their investigations the level of shadow economy does not reflect the level of development. Even in Scandinavia, Denmark or West part of Germany the level of shadow economy can be surprisingly very high one (Cassel \& Cichy, 1986, p. 9). In Poland the shadow economy has been explored by Central Statistical Office (GUS), Ministry of Finance and Institute for Market Economy Research (Instytut Badań nad Gospodarką Rynkową) mainly. Based on their estimations the level of shadow economy has been slowly but constantly decreasing and right now its level constitutes ca. 20\% of GDP (Fudowicz, Łapiński, Peterlik \& Wyżnikiewicz, 2016, p. 14).

\section{METHODOLOGICAL APPROACH}

The goal of the study was to identify the level of the shadow economy in Kujawsko-Pomorskie and Warmińsko-Mazurskie regions. Those regions were chosen because they were regarded to be not best developed and they are closely located. Even though Kujawsko-Pomorski region is situated in the West part of Poland, which it is recognized as better developed as the East part where Warmińsko-Mazurski region is placed. The shadow economy was measured in 2006, 2011 and 2016. The interval of years was foreseen since the change of shadow economy level is better demonstrated. In order to measure the level of shadow economy the MIMIC (Multiple Indicators Multiple Causes) approach was used. The measurement was related to percentage of regional GDP 
in Warmińsko-Mazurski and Kujawsko-Pomorski region. The MIMIC approach is generally widely used in sociology and psychology researches but it proved to be very successful in economics explores as well. It is very comprehensive and since the shadow economy affects different activity simultaneously. Since MIMIC model foreseen numerous determinants it is very suitable in this case. MIMIC method was first presented by Zellner (1970, p. 18) than developed by Joreskog and Goldberger (1975, pp. 8-10). The general idea of research is presented in the graph 1.

Graph 1. MIMIC model of estimation the level of shadow economy in Warmińsko-Mazurskie and Kujawsko-Pomorskie regions

CAUSES

INDICATORS

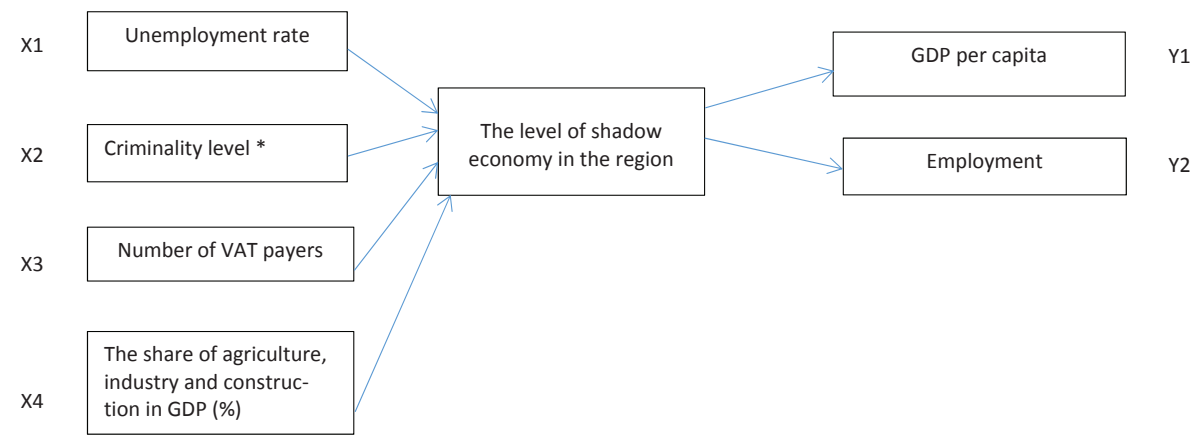

${ }^{*}$ criminality level was calculated by number of criminal acts per 10000 inhabitants.

S o u r c e : own proposition based upon: Tedds, 1998, p. 3.

The MIMIC approach calculates the hidden variable/shadow economy level/ based on observed and measured indicators. The level of shadow economy is linearly explained by known X causes. The MIMIC model consists of two parts:

$$
\begin{aligned}
& \mathrm{S}=\mathrm{pX}+\dot{e} \\
& \mathrm{Z}=\mathrm{d} \mathrm{S}+\ddot{e}
\end{aligned}
$$

In the further step by substituting the first equation into the second one the reduced equation form is obtained.

$$
\mathrm{Z}=\varphi\left(\mathrm{pX}+e^{\prime}\right)+\mu=\mathrm{L} \mathrm{X}+\mathrm{v}
$$


In this way MIMIC model becomes a multi regression function. Structural parameters are appraised with commanding restraints on coefficient matrix L' and the covariance matrix of the error v term. All data used in equitation were appraised by Likehood Procedure, taking this reduced form into consideration and not imposing any restrictions on var-cov matrix. In the third step by the normalization of the reduced equation (3) the matrix L' performed like:

$$
L^{\prime}=\varphi \times \mathrm{p}=\left[\begin{array}{l}
\varphi 1 \\
\varphi 2
\end{array}\right] \times[\mathrm{p} 1+\mathrm{p} 2+\mathrm{p} 3+\mathrm{p} 4 \ldots]
$$

The level of shadow economy in two taken into account regions was measured for 2006, 2011 and 2016, respectively. This was done in this way, since some changes of the shadow economy level can be recognized. All data come out from Statistical Regional Yearbook. Statistica software was applied for calculation.

\section{FINDINGS}

According to the methodological assumption the graph 2 presents the level of shadow economy in Warmińsko-Mazurski and Kujawsko-Pomorski regions.

Graph 2. The level of shadow economy in Warmińsko-Mazurski and Kujawsko-Pomorski regions in 2006, 2011 and 2016 (\% GDP)

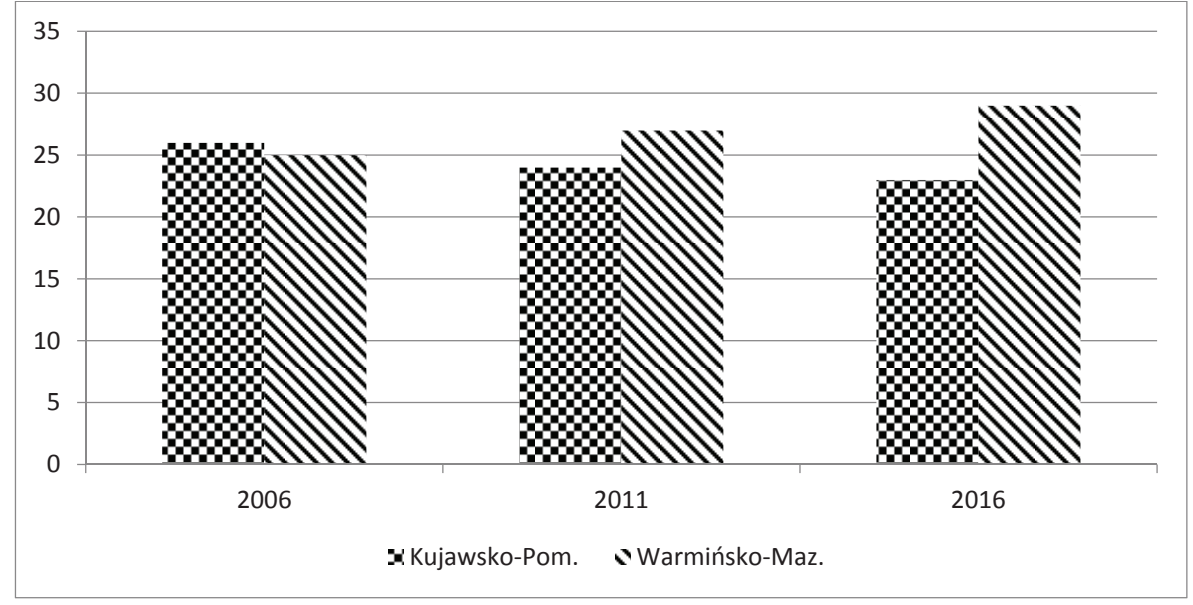

S o u r c e : own calculation. 
In 2006 the level of shadow economy in Kujawsko-Pomorski and WarmińskoMazurski region was quite similar. In Kujawsko-Pomorskie was $26 \%$ of regional GDP but in Warmińsko-Mazurski 25\% regional GDP. In 2011 the situation was modified. In Kujawsko-Pomorski region the level of shadow economy decreased by $2 \%$ of GDP but in Warmińsko-Mazurski region the level of shadow economy expanded till $27 \%$ of GDP. Such a trend was in force later on. In 2016 the level of shadow economy in Kujawsko-Pomorski region was 23\% of GDP and in Warmińsko-Mazurski region 28\% of GDP. Such differentiation supposed to be explained by characteristics of local economics situations. Even though those two regions are regarded not to be the leading of economic development in Poland, there is no significant similarity between them. Individuals in Warmińsko-Mazurski region were mostly employed in industry 23\% (of all working force), agriculture, forestry and fishing 16.5\%, transportation and storage $14.2 \%$, education $9.4 \%$, public administration $6.1 \%$ and construction $5.5 \%$. The province was inhabited by 1.4 million people, GDP per capita was on the level 30745PLN, unemployment rate $14.2 \%$, the number of crime acts per 10,000 inhabitants was 272, the average monthly salary was 3224 PLN. In 2016 the spending on research and development was 126.2 mln PLN. The share of companies that introduced innovation was $22.1 \%$. The revenues of total companies activity was 45682.1 million PLN, and financial result on economic activity 2017.8 million PLN. The rate of financial liquidity was 30.2. (Statistical Yearbook of Warmia and Mazury, 2017, pp. 250-290). In Kujawsko-Pomorski region workers were involved by $23.7 \%$ in industry, $16.9 \%$ in trade and storage, $14.9 \%$ in agriculture, forestry and fishing, $8 \%$ in education and $5.9 \%$ in construction. GDP per capita was on the level of 36766 PLN. The unemployment rate was $10.1 \%$. The average salary was higher than in Warmińsko-Mazurski region 3655 PLN. The level of commercial crimes in Kujawsko-Pomorski region has been declining. In 2016 it was 1402 such acts, but in 2006-2924. Quite high sum of money was spent on research and development - in $2016-289.9$ million PLN. The effect of it was the relatively high share $-34.4 \%$ of all companies which introduced innovation. Revenues of total companies activity has been growing up and in 2016 constitutes 116323.5 million PLN. The financial result on economic activity was positive and created the amount of 5828.2 million PLN. All Assets of companies in 2016 was 40272.6 million PLN. Interesting situation is related to the structure of entities of local economy. Majority of entities - 72.6\% constitutes of natural person conducting economic activity, 8.6\% commercial companies, $6.9 \%$ civil companies and $11.9 \%$ others (Statistical Year- 
book of Kujawsko-Pomorski Region, 2017, pp. 180-256). According to the theoretical assumption natural persons conducting economy are eager to bearing illegal behavior. Taking Kujawsko-Pomorski region into account it should be announcement that this type of entities is not so much affected by the shadow economy. The level of it has been decreasing. The considerable difference between two researched regions in the respects of the shadow economy level and development, except economics situation is the location. Warmińsko-Mazurski region is situated north west of Poland and has the border with Russia-Kaliningrad district. Because of price difference in Russia and Poland of very popular products - like cigarettes, fuel, spirits - those stocks are smuggled to Poland constantly. Apart of that quite often stolen goods from Poland are bootlegging to Russia. This situation with economics background make utterly impact of shadow economy development in Warmińsko-Mazurski region. Since the general economic situation in Warmińsko-Mazurski region (even comparing it to Kujawski-Pomorski region) is not satisfying, that why the shadow economy is desirable option for people to increase their income and improve standard of economic situation. Seems in Kujawsko-Pomorski region (even though the shadow economy is on high level) inhabitants follow more legal way to enhance their financial status.

\section{CONCLUSIONS}

Albeit the level of shadow economy in Kujawsko-Pomorski region in the beginning of analyzed period was higher than in Mazursko-Warmiński region in following years its level declined. Contradictory situation was observed in Mazursko-Warmiński region. After 2006 the level of shadow economy increased, reaching in $2016-28 \%$ of regional GDP. Such process should be connected with general economic situation in the regions. Kujawsko-Pomorski region proved to be more effective one and its overall economic conditions are better. This makes less space for the shadow economy development. Additionally to that the location of Warmińsko-Mazurski region, bordering with Kaliningrad district creates impact for shadow economy activity. Furthermore the general conclusion related to Poland may be raised - the less developed regions supposed to be categorized by higher level of the shadow economy. This research provides impulse for another set of studies. Further studies should be focused on selected economic data characterizing overall situation in the respect of effectiveness shadow economy performance. 


\section{REFERENCES}

Adam, M., \& Ginsburgh, C.V. (1985). The effects of irregular markets on macroeconomic policy: some estimates for Belgium. European Economic Review, 29(1), 15-33.

Aldridge, J., \& Decary-Hetu, D. (2015). A response to Dolliver's. Evaluating drug trafficking on the Tor Network: Silk Road 2, the sequel. International Journal of Drug Policy, 26(11), 1124-1125. http://dx.doi.org/10.1016/j.drugpo.2015.05.017.

Bilonizhko, 0. (2006). Measurement and Determinates of the Hidden Economy in Regions in Ukraine and Russia: MIMIC approach. Kyiv: National University "Kyiv-Mohyla Academy" Economics Education and Research Consortium Master's Program in Economics.

Buszko, A. (2016). Mechanizmy szarej strefy. (Mechanisms of the Shadow Economy.) Warszawa. CeDeWu.

Buszko, A. (2017a). The Impact of the Shadow Economy on Small and Medium Sized Companies in Poland. A Barrier or an Opportunity for Growth? International Journal of Business and Economic Development, 5(2), 34-44.

Buszko, A. (2017b). Critical Approach to the Traditional Way of Shadow Economy Measurement. In МАТЕРИАЛЫ МЕЖДУНАРОДНОЙ НАУЧНО-ПРАКТИЧЕСКОЙ ДИСТАНЦИОННОЙ КОНФЕРЕНЦИИ «РАЗВИТИЕ РЫНКА ФИНАНСОВЫХ УСЛУГ В ТАДЖИКИСТАНЕ И ПОЛЬШЕ», Dushanbe.

Buszko, A. (2018). Cultural Implications for the Shadow Economy. Engineering Economics, 29(1), 46-52. http://dx.doi.org/10.5755/j01.ee.29.1.18069.

Cassel, D., \& Cichy, U. (1986). Explaining the Growing Shadow Economy in East and West: A Comparative System Approach. Comparative Economy Studies, 28, 20-41.

Chen, M. (2007). Rethinking the Informal Economy: Linkages with the Formal Economy and the Formal Regulatory Environment, http://www.un.org/esa/desa/papers/2007/wp46_2007.pdf (accessed: 30.05.2018).

Christopoulos, D.K. (2003). Does the underground economy respond symmetrically to tax changes? Evidence from Greece. Economic Modelling, 20, 563-570.

Dell'Anno, R. (2003). Estimating the shadow economy in Italy: a structural equation approach, working paper, http://www.ftp.econ.au.dk/afn/wp/03/wp03_07.pdf (accessed: 30.05.2018).

Dell'Anno, R., Gómez-Antonio, M., \& Pardo, A. (2007). The shadow economy in three Mediterranean countries: France, Spain and Greece. A MIMIC approach. Empirical Economics, 33(1), 51-84. http://dx.doi.org/10.1007/s00181-007-0138-1.

Elgin, E., \& Öztunali, O. (2015). Shadow Economies around the World: Model Based Estimates, http://www.econ.boun.edu.tr/public_html/RePEc/pdf/201205.pdf (accessed: 30.05.2018).

Florea, A., \& Schiop, C. (2008). Are there any positive consequences of underground economy? Fascicle of Management and Technological Engineering, 7 (17), 2219-2222.

Fudowicz, J., Łapiński, K., Peterlik, M., \& Wyżnikiewicz, B. (2016). Szara strefa w polskiej gospodarce w 2016 roku. (The Shadow Economy in Polish Economy in 2016.) Warszawa: Instytut Badań nad Gospodarką Rynkową (Institute for Market Economy Research. Warsaw). 
Joreskog, K., \& Goldberger, A. (1975). Estimation of a Model with Multiple Indicators and Multiple Causes of a Single Latent Variable. Journal of the American Statistical Association, 70(351), 631-639.

Komarova, T. (2003). Hidden economy in Russian Counted? Kyiv: Institute for Economic Research and Policy Consulting.

Krakowski, M. (2005). Determinants of the Informal Economy: The Importance of Regional Factors, working paper, https://www.econstor.eu/bitstream/10419/19285/1/313. pdf (accessed: 30.05.2018).

Laruelle, M. (2008). The concept of ethnogenesis in Central Asia: political context and institutional mediators (1940-50). Kritika: Explorations in Russian and Eurasian History, 9(1), 169-188. http://dx.doi.org/10.1353/kri.2008.0005.

Mara, E. (2008). Causes and Consequences of Underground Economy. MPRA Paper, $36438,1109-1116$.

Nikolayenko, S., Lissovolic, Y., \& MacFarquar, R. (1997). Special Report: The Shadow Economy in Russia's Regions. Russian Economic Trends, 4.

Putniņš, T., \& Sauka, A. (2015). Measuring the shadow economy using company managers. Journal of Comparative Economics, 43(2), 471-490. http://dx.doi.org/10.1016/j. jce.2014.04.001.

Salatin, P., \& Jahani, T. (2016). Effect of Regulatory Burden on Black Economy in Selected Countries Group. International Journal of Management, Accounting and Economics, 3(9), 521-531.

Schneider, F. (2005). Shadow economies around the world: what do we really know? European Journal of Political Economy, 21(3), 598-642. http://dx.doi.org/10.1016/j.ejpoleco.2004.10.002.

Schneider, F. (2010). The influence of public institutions on the shadow economy: an empirical investigation for OECD countries. Review of Law and Economics, 6(3), 441-468. http://dx.doi.org/10.2202/1555-5879.1542.

Tafenau, E., Herwartz, H., \& Schneider, F. (2010). Regional Estimates of the Shadow Economy in Europe. International Economic Journal, 24(4), 629-636. http://dx.doi. org/10.1080/10168737.2010.526010.

Tedds, L. (1998). Measuring the Size of the Hidden Economy in Canada: a LatentVariable/ MIMIC Model Approach. Victoria: Department of Economics, University of Victoria.

Thießen, U. (2015). The Shadow Economy in International Comparison: Options for Economic Policy Derived from an OECD Panel Analysis. International Economic Journal, 24(4), 481-509. http://dx.doi.org/10.1080/10168737.2010.525986.

Urząd Statystyczny w Bydgoszczy (Statistical Office Bydgoszcz) (2017). Rocznik Statystyczny Województwa Kujawsko-Pomorskiego. (Statistical Yearbook of Kujawsko-Pomorski Region.)

Urząd Statystyczny w Olsztynie (Statistical Office Olsztyn) (2017). Rocznik Statystyczny Województwa Warmińsko-Mazurskiego. (Statistical Yearbook of Warmia and Mazury Region.).

Wiseman, T. (2013). U.S. shadow economies: a state-level study. Constitutional Political Economy, 24(4), 310-335. http://dx.doi.org/10.2139/ssrn.2208637. 
Vorobyev, P. (2015). Estimating Informal Share in Russian Regions. Economics Education Research Consortium Working Paper, E15(02).

Zellner, A. (1970). Estimation of Regression Relationships Containing Unobservable Variables. International Economic Review, 11(3), 441-454. 